\title{
An improved tangency condition for fog formation in cooler-condensers
}

\author{
H. J. H. BROUWERS \\ Akzo Research Laboratories Arnhem, Fibers and Polymers Division, Department of Mechanical \\ Engineering, Velperweg 76, 6824 BM Arnhem. The Netherlands
}

(Received 28 March 1990)

\begin{abstract}
In 1950 Johnstone et al. (Ind. Engng Chem. 42, 2298-2302 (1950)) introduced the tangency condition to determine fog (or mist) formation in binary mixtures in cooled channels. In the present analysis it is demonstrated that their condition is erroneous and an improved equation is derived. The condition is based on the heat and diffusional mass transfer rates to a condenser wall, and the slope of the saturation line of the vapour component at the wall temperature. The transfer rates follow from a thorough analysis of the energy and diffusion equation in a stagnant film next to the wall (the classical 'film model' or "film theory"). The validity of the improved tangency condition is assessed against wall condensation experiments by Johnstone et al., concerning mixtures of nitrogen with vapours of water and n-butyl alcohol, yielding satisfactory agreement.
\end{abstract}

\section{INTRODUCTION}

A PIONEERING article on fog formation in mixtures of noncondensables and vapour in cooled channels has been published by Johnstone et al. [1]. On the basis of a film model analysis the tangency condition was derived to determine the critical wall temperature for fog formation in flowing binary mixtures in the presence of wall condensation. This condition followed from a consideration of the vapour pressure and temperature gradients at the wall, which were compared with the slope of the saturation line at the wall temperature. Until now the condition has been used unaltered to examine fog formation, see the extensive reviews by Sekulic [2] and Koch [3] of subsequent literature in the field of fog formation.

Experiments were furthermore performed by Johnstone et al. [1] with mixtures of nitrogen and vapours of sulphur, $\mathrm{n}$-butyl alcohol and water to validate the derived condition. Two experimental departures from the theoretical predictions of (no) fog formation were observed, namely:

(a) no fog formation, though predicted, and,

(b) fog formation, though superheating was proved theoretically.

The former deviation could be attributed to the absence of sufficient nuclei in the gas flow, although in the examined mixtures extra nuclei were generated artificially. The second discrepancy, only found with film condensation of n-butyl alcohol and dropwise condensation of water, could not be explained satisfactorily.

In this paper it is shown that Johnstone et al. [1] employed an erroneous equation to investigate fog formation; the improved tangency equation will be derived here. Furthermore, the nitrogen-water vapour condensation experiments of Johnstone et al. [1] are found to correlate excellently with this improved condition.

\section{BASIC EQUATIONS OF THE FILM AND THEIR SOLUTIONS}

In this section the profiles of the vapour mole fraction and temperature in a stagnant film are derived. The required basic equations of diffusion and energy can be found in Bird et al. [4].

In the film-a steady-state system in which variations in the $x$-direction (which will later be identified with the direction of flow in a channel) are neglectedthe local mass balance equation, see Fig. 1 , is

$$
v \rho^{+} \frac{\mathrm{d} c^{+}}{\mathrm{d} y}=\rho^{+} \mathbb{D} \frac{\mathrm{d}^{2} c^{+}}{\mathrm{d} y^{2}}
$$

where $v$ is given by

$$
v=-\frac{\mathbb{D}}{1-c^{+}} \frac{\mathrm{d} c^{+}}{\mathrm{d} y} .
$$

This velocity is traditionally referred to as 'convective velocity', 'bulk flow', or 'Stefan flow'. It is induced by the flow of vapour through the mixture and plays an important role in mixtures with a high vapour mole fraction. The boundary conditions on $c^{+}$, see Fig. 1, are

$$
\begin{gathered}
c^{+}(y=0)=c_{\mathrm{i}}^{+} \\
c^{+}\left(y=\delta_{\mathrm{c}}\right)=c_{\mathrm{b}}^{+}
\end{gathered}
$$

where $c_{i}^{+}$is the vapour mole fraction at the interface and $c_{\mathrm{b}}^{+}$the mole fraction of the bulk. Substituting equation (2) in equation (1), solving the resulting 


\section{NOMENCLATURE}

$c^{+} \quad$ vapour mole fraction

$c_{p}^{+} \quad$ molar specific heat [ $\left.\mathrm{J} \mathrm{kmol}^{-1} \mathrm{~K}^{-1}\right]$

II diffusion coefficient $\left[\mathrm{m}^{2} \mathrm{~s}^{-1}\right]$

$D_{\mathrm{h}} \quad$ hydraulic diameter [m]

$F^{+}$saturation function, see equation (14)

$G^{+}$relation between $c^{+}$and $l$ in the superheated region

$g$ mass transfer coefficient $\left[\mathrm{kmol} \mathrm{m}^{-2} \mathrm{~K}\right.$ ']

$h$ heat transfer coefficient $\left[\mathrm{W} \mathrm{m} \mathrm{m}^{-2} \mathrm{~K}^{-1}\right]$

$k$ thenlmal conductivity [W $\left.\mathrm{m}^{\cdots-1} \mathrm{~K}^{\cdots}\right]$

Le $\quad$ Lewis number, $k / \rho^{+} c_{p}^{+} \mathbb{D}$

$N_{u} \quad$ Nusselt number, $h D_{h} / k$

$P$ pressure [bar]

Re Reynolds number, $u \rho D_{\mathrm{h}} / \eta$

$S h \quad$ Sherwood number, $g D_{\mathrm{h}} / p^{+} \mathbb{D}$

$T$ absolute temperature [K]

$t$ temperature [ $\mathrm{C}$ ]

$u$ component of velocity in the $x$-direction [ $\left.\mathrm{m} \mathrm{s}^{-1}\right]$

$v \quad$ component of velocity in the $y$-direction $\left[\mathrm{ms}^{-1}\right]$ $x, y$ coordinates $[\mathrm{m}]$.

Greek symbols

$\delta$ film thickness $[\mathrm{m}]$

$\eta \quad$ dynamic viscosity [Pa s]

0 correction factor

$\rho$ density $\left[\mathrm{kg} \mathrm{m}^{-}\right]$

$\rho^{+}$molar density $\left[\mathrm{kmol} \mathrm{m}^{-3}\right]$.

\section{Subscripts}

$\begin{array}{ll}\text { a } & \text { critical interface condition } \\ \text { b } & \text { bulk } \\ \text { c } & \text { diffusional } \\ \text { i } & \text { condensate (or wall)/gas interface } \\ n & \text { noncondensables } \\ \text { sat } & \text { saturation } \\ \text { t } & \text { thermal } \\ \text { tot } & \text { total } \\ v & \text { vapour. }\end{array}$

differential equation, and applying cquations (3) and (4), produces

$$
c^{+}(y)=1+\left(c_{i}^{+}-1\right) \exp \left\{\frac{y}{\delta_{c}} \ln \left(\frac{1-c_{b}^{+}}{1-c_{i}^{+}}\right)\right\} .
$$

This solution for the vapour mole fraction in a film was first obtained by Stefan [5].

The energy equation for the film, neglecting viscous dissipation, internal heat sources and radiation, is

$$
\rho^{+} c_{p}^{+} t \frac{\mathrm{d} t}{\mathrm{~d} y}+\rho^{+} \mathrm{D}\left(c_{p, n}^{+}-c_{p, v}^{+}\right) \frac{\mathrm{d} c^{+}}{\mathrm{d} y} \frac{\mathrm{d} t}{\mathrm{~d} y}=k \frac{\mathrm{d}^{2} t}{\mathrm{~d} y^{2}} .
$$

The second term on the left-hand side represents the well-known Ackermann term. The boundary conditions on $t$ are

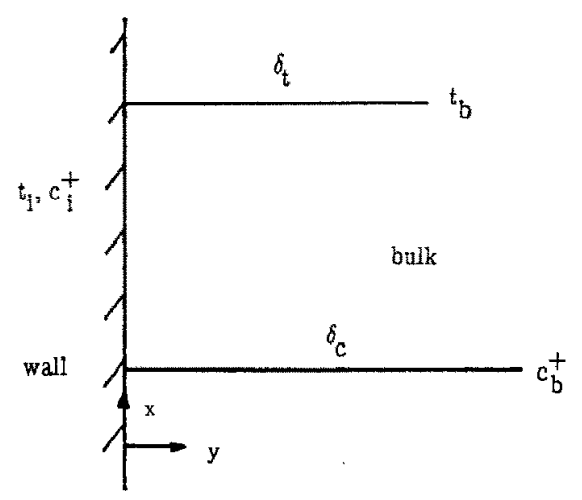

Fro. 1. The film.

$$
\begin{gathered}
t(y=0)=t_{\mathrm{i}} \\
t\left(y=\hat{\delta}_{\mathrm{t}}\right)=t_{\mathrm{b}}
\end{gathered}
$$

Substituting the relation between the mixture's molar specific heat and its composition

$$
c_{p}^{+*}=c^{+} c_{p, v}^{+}+\left(1-c^{+}\right) c_{p, n}^{+}
$$

and equations (2) and (5) into equation (6), solving the resulting equation and applying boundary conditions (7) and (8), yields the temperature in the film

$$
t(y)=\left(t_{b}-t_{\mathrm{i}}\right)\left[\begin{array}{c}
\exp \left\{\begin{array}{c}
c_{p, y}^{+} y \\
L e c_{y}^{+} \delta_{c}
\end{array} \ln \left(\frac{1-c_{b}^{+}}{1-c_{\mathrm{i}}^{+}}\right)\right\}-1 \\
\exp \left\{\frac{c_{p, v}^{+} \delta_{1}}{L e^{*} c_{p}^{+} \delta_{\mathrm{c}}} \ln \left(\frac{1-c_{\mathrm{b}}^{+}}{1-c_{\mathrm{i}}^{+}}\right)\right\}-1
\end{array}\right]+t_{\mathrm{i}}
$$

where

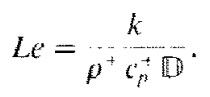

Equation (10) has been derived independently by Ackermann [6] and Colburn and Drew [7]. The latter authors also applied the film model expressions to convective heat and mass transfer in a closed channel. The bulk values of temperature and vapour mole fraction are then taken to be the mixed mean values, while $\delta_{1}$ and $\delta_{\mathrm{c}}$ are taken to be $D_{\mathrm{h}} / N u$ and $D_{\mathrm{h}} / S h$, where $N u$ and $S h$ denote the Nusselt and Sherwood number in the absence of mass transfer. In the next section these 
film model expressions are used to investigate supersaturation in the mixture.

\section{THE FOG FORMATION CONDITION}

In order to obtain a relation between $c^{+}$and $t$ in the film, which can then be compared with the saturation line, the coordinate $y / \delta_{\varepsilon}$ is eliminated from equations (5) and (10), yielding

$$
\begin{aligned}
c^{+}= & G^{+}(t)=1+\left(c_{i}^{+}-1\right)\left(\frac{t-t_{\mathrm{i}}}{t_{\mathrm{b}}-t_{\mathrm{i}}}\right. \\
& \left.\times\left(\exp \left\{\frac{c_{p, y}^{+} \delta_{\mathrm{i}}}{c_{p}^{+} \operatorname{Le} \delta_{\mathrm{c}}} \ln \left(\frac{1-c_{\mathrm{b}}^{+}}{1-c_{\mathrm{i}}^{+}}\right)\right\}-1\right)+1\right)^{\left(L_{t} c_{r}^{+}\right) / c_{p, v}^{+}} .
\end{aligned}
$$

This relation is a monotonically increasing function of $t$, since the first derivative of $G^{+}(t)$ with respect to $t$ is positive

$$
\begin{aligned}
\frac{\mathrm{d} G^{+}}{\mathrm{d} t} & =\frac{\operatorname{Le} c_{p}^{+}}{c_{p, v}^{+}}\left(\frac{c_{\mathrm{i}}^{+}-1}{t_{\mathrm{b}}-t_{\mathrm{i}}}\right) \\
& \times\left(\exp \left\{\frac{c_{p, \mathrm{v}}^{+} \delta_{\mathrm{t}}}{c_{p}^{+} \operatorname{Le} \delta_{\mathrm{c}}} \ln \left(\frac{1-c_{\mathrm{b}}^{+}}{1-c_{\mathrm{i}}^{+}}\right)\right\}-1\right)\left(\frac{t-t_{\mathrm{i}}}{t_{\mathrm{b}}-t_{\mathrm{i}}}\right. \\
& \left.\times\left(\exp \left\{\frac{c_{p, \mathrm{v}}^{+} \delta_{\mathrm{i}}}{c_{p}^{+} L e \delta_{\mathrm{c}}} \ln \left(\frac{1-c_{\mathrm{b}}^{+}}{1-c_{\mathrm{i}}^{+}}\right)\right\}-1\right)+1\right)^{\left.\left(\operatorname{Lsc} c_{p}^{+}\right) c_{p, v}^{+}\right)-1}
\end{aligned}
$$

For $\left(L e c_{p}^{+}\right) / c_{p^{+}, v}^{+}>1$ the function $G^{+*}(t)$ is concave, $G^{+}(t)$ is a straight line for $\left(\right.$ Le $\left.c_{p}^{+}\right) / c_{p, v}^{+}=1$, while $G^{+}(t)$ is a convex curve for $\left(L e c_{p}^{+}\right) / c_{p, v}^{+}<1$. These properties follow from the second derivative of $G^{+}(t)$ with respect to $t$. The vapour mole fraction on the saturation line follows from

$$
c^{+}=F^{+}(t)=\frac{P_{v s a t}(t)}{P_{\text {tot }}}
$$

At the wall, denoting here the condensate/gas interface, $c_{i}^{+}=F^{+}\left(t_{i}\right)$ prevails. On the basis of a consideration of vapour and temperature profiles, the following slope condition is suggested to examine whether supersaturation occurs in a condenser:

$$
\begin{aligned}
\left.\frac{\mathrm{d} c^{++}}{\mathrm{d} y}\right|_{y=0}=\left.\frac{\mathrm{d} G^{+}}{\mathrm{d} t}\right|_{t=r_{\mathrm{i}}}=\frac{\operatorname{Lec} c_{p}^{+}}{c_{p, v}^{+}}\left(\frac{c_{\mathrm{i}}^{+}-1}{t_{\mathrm{b}}-t_{\mathrm{i}}}\right) \\
\left.\frac{\mathrm{d} t}{\mathrm{~d} y}\right|_{y=0} \\
\quad \times\left(\exp \left\{\frac{c_{p, v}^{+} \delta_{\mathrm{t}}}{c_{p}^{+} \text {Le } \delta_{\mathrm{c}}} \ln \left(\frac{1-c_{\mathrm{b}}^{+}}{1-c_{\mathrm{f}}^{+}}\right)\right\}-1\right)>\left.\frac{\mathrm{d} F^{+}}{\mathrm{d} t}\right|_{t=t_{\mathrm{i}}}
\end{aligned}
$$

which is based on the slopes of $F^{+}(t)$ and $G^{+}(t)$ in $t=t_{\mathrm{i}}$. From this equation and the saturation con- dition (implicitly excluding the possibility of supersaturation) fog formation can be detected.

The lowest permissible $t_{1}$ at which fog is not yet formed, denoted as $t_{\mathrm{a}}$, is obtained when equation (15) is an equality. Applying equation (13) and rewriting equation (15) then yields as the tangency condition

$$
\left.\frac{\mathrm{d} F^{+}}{\mathrm{d} t}\right|_{t=t_{\mathrm{s}}}=\left.\frac{\mathrm{d} G^{+}}{\mathrm{d} t}\right|_{t=t_{\mathrm{s}}}=\frac{\delta_{\mathrm{t}} \theta_{\mathrm{c}}^{+}}{\delta_{\mathrm{c}} \theta_{\mathrm{l}}^{+}} \frac{c_{\mathrm{b}}^{+}-c_{\mathrm{a}}^{+}}{t_{\mathrm{b}}-t_{\mathrm{a}}}
$$

where $c_{\mathrm{a}}^{+}$denotes the critical interface mole fraction $\left(c_{\mathrm{a}}^{+}=F\left(t_{\mathrm{a}}\right)\right)$. In this equation the thermal (Ackermann) correction factor is introduced as

$$
\theta_{\mathrm{t}}^{+}=\frac{\frac{c_{p, v}^{+} \delta_{\mathrm{t}}}{L e c_{p}^{+} \delta_{\mathrm{c}}} \ln \left(\frac{1-c_{\mathrm{b}}^{+}}{1-c_{\mathrm{a}}^{+}}\right)}{\operatorname{cxp}\left\{\frac{c_{p, v}^{+} \delta_{\mathrm{t}}}{L e c_{p}^{+} \delta_{\mathrm{c}}} \ln \left(\frac{1-c_{\mathrm{b}}^{+}}{1-c_{\mathrm{a}}^{+}}\right)\right\}-1}
$$

and the diffusional mass transfer correction factor as

$$
\theta_{c}^{+}=\frac{\ln \left(1-\frac{c_{b}^{+}-c_{a}^{+}}{1-c_{\mathrm{a}}^{+}}\right)}{-\frac{c_{b}^{+}-c_{a}^{+}}{1-c_{\mathrm{a}}^{+}}}
$$

Both these conventional film model correction factors can be found in Bird et al. [4], and are widely used in practice. For $t_{i}<t_{\mathrm{d}}$, a part of the film is fogging $\left(t_{\mathrm{i}} \leqslant t \leqslant t_{\mathrm{a}}\right)$, in this part $t$ and $c^{+}$are coupled by equation (14). In the superheated part $\left(t_{\mathrm{a}} \leqslant t \leqslant t_{\mathrm{b}}\right) c^{+}=G^{+}(t)$ prevails. In Fig. 2 the physical principles of equations (15) and (16) are illustrated graphically. Johnstone $e t$ al. [1] were the first to employ the principle of the slope and tangency condition to assess fog formation. However, they used an incorrect expression, as will be explanned below.

Their expression for the critical $t_{\mathrm{i}}$ ("equation (9)') is obtained when in equations (15)-(17) are substituted

$$
\frac{\delta_{t}}{\delta_{c}}-\frac{S h}{N u}=L e^{1 / 3}
$$

and

$$
c_{p, v}^{+}=c_{p}^{+}
$$

and

$$
\theta_{i}^{+}=1
$$

Equation (19) is applicable to turbulent flow (the socalled Chilton-Colburn analogy) and to forced convective laminar flow in the entrance region of a channel. Johnstone $e t$ al. [1] experimentally examined laminar flow $(R e \cong 700)$ of binary mixtures in this region of a circular tube. Approximation (20) implies that $c_{p, v}^{+}=c_{p, 1}^{+}$, see equation (9), and introduces an unacceptable inaccuracy. This is particularly the case with nitrogen and n-butyl alcohol mixtures (n-butyl alcohol, $c_{p, v}^{+} \cong 135 \mathrm{~kJ} \mathrm{kmol}^{-1} \mathrm{~K}^{-1}$; water, $c_{p, v}^{+} \cong 34 \mathrm{~kJ}$ $\mathrm{kmol}^{-1} \mathrm{~K}^{-1}$; nitrogen, $c_{p, \mathrm{n}}^{+} \cong 28 \mathrm{~kJ} \mathrm{kmol}^{-1} \mathrm{~K}^{-1}$ ). 


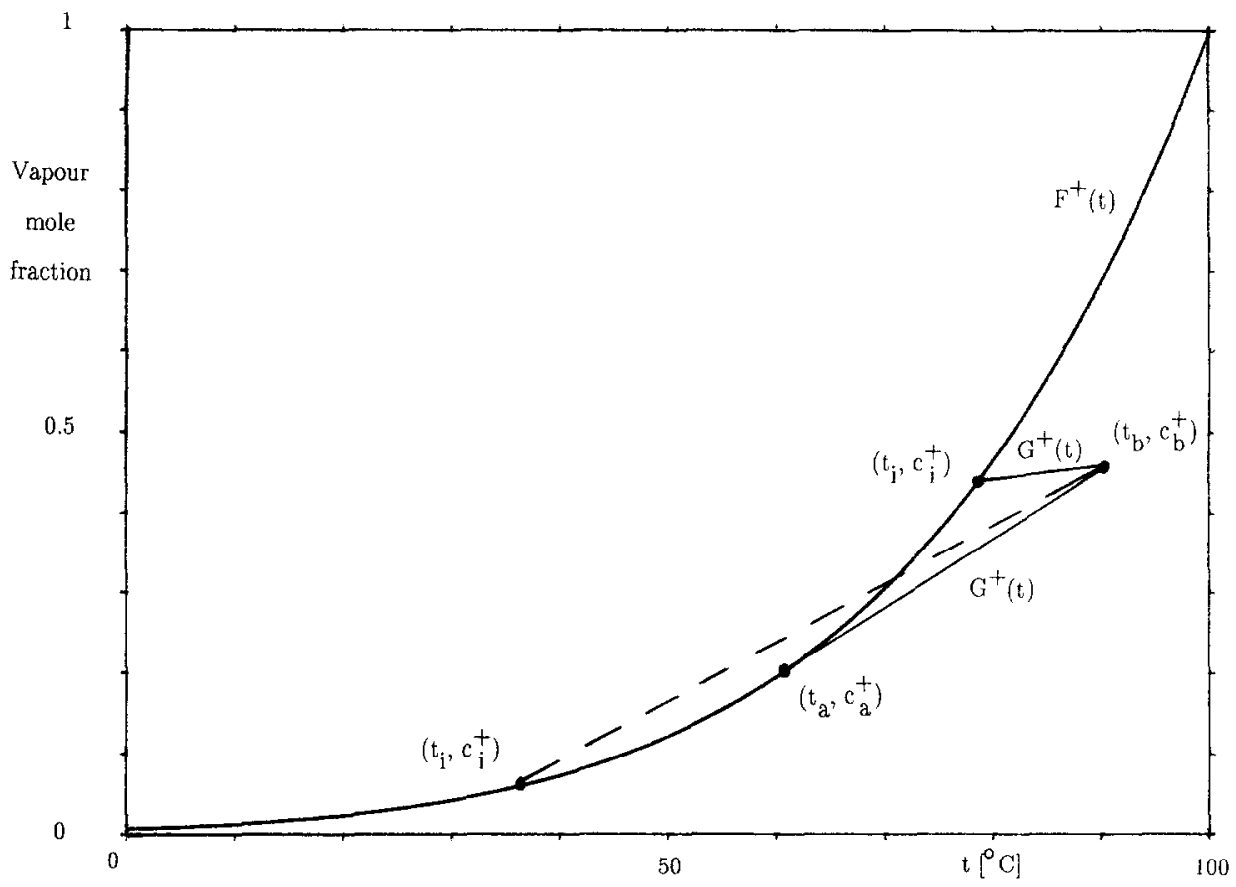

FIG. 2. Determination of $t_{\mathrm{a}}$ and prediction of fog formation (for $\left(\right.$ Le $\left.c_{p}^{+}\right) / c_{p, \mathrm{~s}}^{+}=1$ and $\delta_{\mathrm{c}}=\delta_{\mathrm{i}}$ ).

Approximation (20) actually follows from a film model analysis where the Ackermann term in energy equation (6) is not taken into account. Assumption (21) is not correct either, since the diffusion correction factor $\theta_{i}^{+}$is of the same order of magnitude as the thermal correction factor; they are even identical when $\left(L e c_{p}^{+}\right) / c_{p, y}^{+}=1$. Equation (21) follows, in fact, from a film model analysis where the effect of the induced velocity on diffusion is neglected. The introduction of equations (20) and (21) might therefore be the reason why Johnstone et al. [1] observed discrepancies between some experiments and theory. In the next section these cases are discussed in some detail

It is interesting to realize that the negative effect of equations (20) and (21) is less pronounced for mixtures with dilute vapour. To these mixtures the following applies; namely that $\theta_{c}^{+} \cong 1$ and $\theta_{1}^{+} \cong 1$, since $c_{\mathrm{i}}^{+}<c_{\mathrm{b}}^{+} \ll 1$. To determine fog formation and assess the boundary of the superheated and saturated regions in flowing mixtures of dilute wall condensing water vapour (with $0_{\mathrm{c}}^{+}=0_{\mathrm{t}}^{+}=1$ ) in air, equations (15) and (16) have been applied fruitfully in linearized form by Toor [8,9] (with $\delta_{1} / \delta_{\mathrm{c}}=S h / N u=1$ ). Koch [3] $\left(\delta_{\mathrm{t}} / \delta_{\mathrm{c}}=1\right)$ and Hayashi et al. [10] $\left(\delta_{1} / \delta_{c}=L e^{0.36}=0.95\right)$.

Using equation (15) (or equation (16)) fog can be detected. But on the other hand, if equation (15) is not fulfilled, superheating in the entire film is not necessarily guaranteed. This aspect of criterion (15) is discussed in the following. For $\left(L e c_{p}^{+}\right) / c_{p, y}^{++} \geqslant 1$ superheating can be examined correctly with equation (15), since $G^{+}(t)$ is a straight line or a concave curve. whereas $F^{+}(t)$ is convex. However, for $\left(L e c_{p}^{+}\right)$ $c_{p, v}^{+}<1$, it is theoretically possible that equation (15) predicts no fog formation, while both convex curves $F^{\prime}(t)$ and $G^{+}(t)$ intersect in the film. In Fig. 3 an example of such a supersaturation case in the film is depicted.

\section{CONDENSATION EXPERIMENTS}

The experimental results of Johnstone et al. [1] are now compared with the correct criterion for fog formation. We are particularly interested in the cases where fog was not predicted by the erroneous equations (16)-(21), though fog formation was observed for some situations. The introduction of equation (20) results namely in too high a value of $t_{i z}$ (since $\left.c_{p, y}^{+}>c_{p}^{+}\left(>c_{p, n}^{+}\right)\right)$, while assumption (21) causes too low a value of $t_{\mathrm{a}}\left(\right.$ since $\left.\Theta_{c}^{+}>1\right)$, sec equation (16). The net result of both introductions could be too low a value of $t_{\mathrm{i}}$, resulting in an crroneous theoretical prediction of a superheated mixture and hence no fog formation. These situations were found only with mixtures of nitrogen and vapours of n-butyl alcohol and water, which are therefore treated herc.

In Table I the experimental data for water vapour nitrogen mixtures are listed, while in Table 2 those of n-butyl alcohol-nitrogen mixtures are summarized. In these tables $t_{\mathrm{i}}$ and the related predictions of Johnstone et al. [1] regarding fog formation are included. Using equations (16)-(19) the improved critical temperalures $t_{\mathrm{a}}$ are now re-determined. As the physical properties of air and nitrogen are very similar, the physical properties of air are used here, taken from 


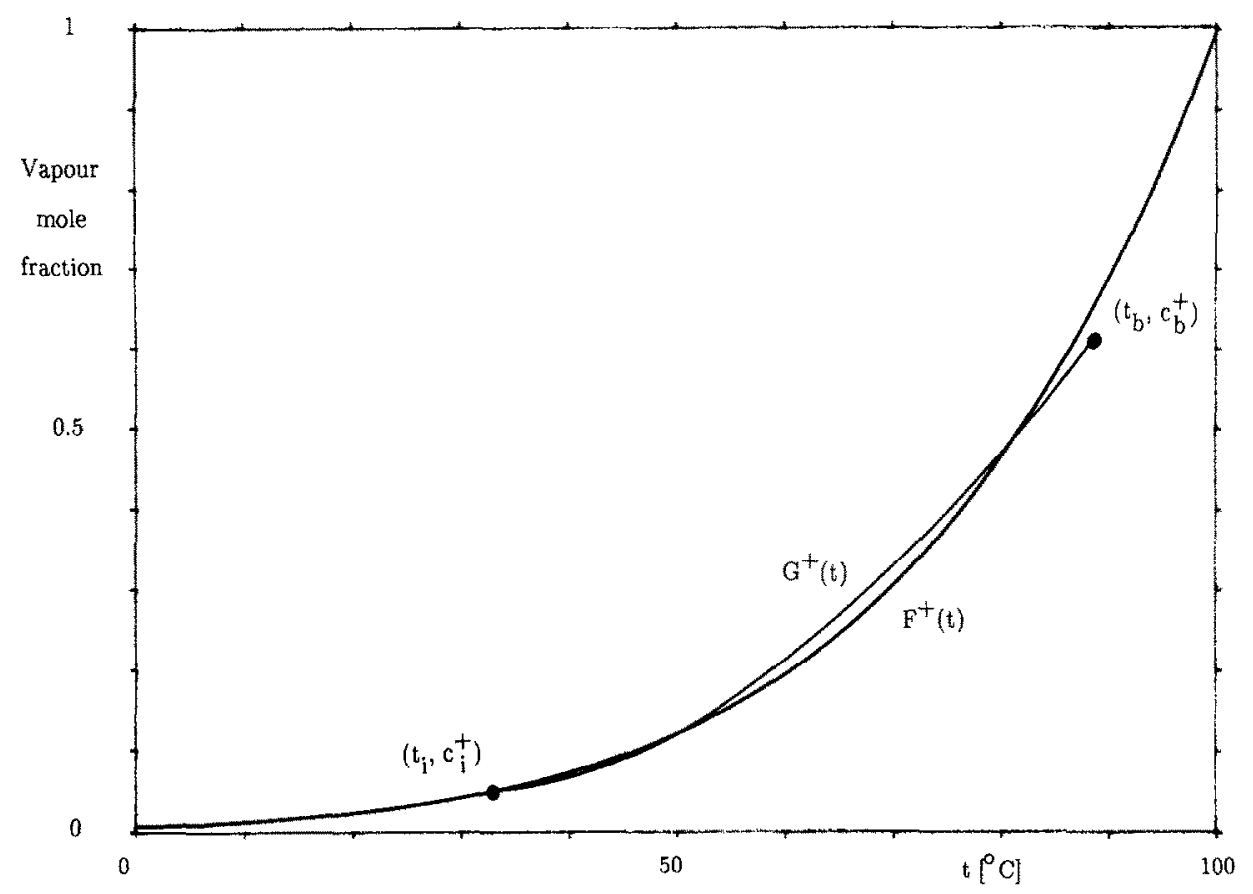

Fig. 3. Erroneous prediction of a superheated film with equation (15) for $\left(\right.$ Le $\left.c_{p}^{+}\right) / c_{p, v}^{+}<1$ and $\delta_{s}=\delta_{\mathrm{t}}$.

V.D.I. [11]. The latter is also used to supply the properties of water vapour. The diffusion coefficient of both gases is given by Edwards et al. [12] as

$$
\mathbb{D} /\left[\mathrm{m}^{2} \mathrm{~s}^{-1}\right]=1.758 \times 10^{-4} \frac{(T /[\mathrm{K}])^{1.685}}{P_{\mathrm{tot}} /[\mathrm{Pa}]}
$$

The molar specific heat $c_{p, v}^{+}$of n-butyl alcohol is taken from Reid et at. [13], and the values of $k$ and $\mathbb{D}$ of this vapour, provided by Landolt-Börnstein [14], are approximated by

$$
\begin{array}{r}
k /\left[\mathrm{W} \mathrm{m}^{-1} \mathrm{~K}^{-1}\right]=11.88 \times 10^{-3}+t /\left[{ }^{\circ} \mathrm{C}\right]\left(5.54 \times 10^{-5}\right. \\
\left.+2.155 \times 10^{-7} t /\left[{ }^{\circ} \mathrm{C}\right]\right)
\end{array}
$$

$$
\mathbb{D} /\left[\mathrm{m}^{2} \mathrm{~s}^{-1}\right]=0.74 \times 10^{5}\left(\frac{T /[\mathrm{K}]}{273}\right)^{1,72}
$$

The molar densities $\rho^{+}$of all the mixtures are simply determined using the ideal gas law, in combination with $P_{\mathrm{tol}}=1 \mathrm{~atm} \quad(=1.01325$ bar $)$. The Antoine relations for the saturation pressures of both vapours stem from Reid et al. [13]. These vapour pressures yield saturation lines for both mixtures which correspond excellently to the lines drawn by Johnstone et al. [1] ('Fig. 2' and 'Fig. 3'). The saturation lines in

\begin{tabular}{|c|c|c|c|c|c|c|c|c|}
\hline \multirow[b]{2}{*}{$c_{b}^{+}$} & \multicolumn{4}{|c|}{ Johnstone et al. [1] } & \multirow[b]{2}{*}{ Observation } & \multicolumn{3}{|c|}{ Equations (16)-(19) } \\
\hline & $\left.t_{\mathrm{b}} \backslash \mathrm{C}\right]$ & $t_{\mathrm{i}}[\mathrm{C}]$ & $t_{\mathrm{a}}\lfloor\mathrm{C}\rfloor$ & Prediction & & $t_{\mathrm{a}}[\mathrm{C}]$ & Prediction & $L e$ \\
\hline 0.101 & 111.0 & 12.0 & 8.0 & no fog & no fog & 10.1 & no fog & 0.84 \\
\hline 0.101 & 110.0 & 10.7 & 8.3 & no fog & no fog & 10.3 & no fog & 0.84 \\
\hline 0.098 & 107.0 & 9.6 & 8.5 & no fog & no fog & 10.3 & fog & 0.84 \\
\hline 0.097 & 105.0 & 8.3 & 8.3 & critical value & no fog & 10.4 & fog & 0.84 \\
\hline 0.125 & 110.0 & 13.7 & 12.6 & no fog & no fog & 14.4 & fog & 0.83 \\
\hline 0.123 & 111.0 & 12.4 & 12.4 & critical value & fog & 13.9 & fog & 0.83 \\
\hline 0.123 & 112.5 & 12,0 & 12.0 & critical value & fog & 13.7 & fog & 0.83 \\
\hline 0.095 & 123.5 & 11.1 & 5.0 & no fog & no fog & 7.0 & no fog & 0.84 \\
\hline 0.100 & 134.0 & 6.0 & 4.5 & nofog & no fog & 6.5 & fog & 0.84 \\
\hline 0.102 & 136.5 & 4.7 & 4.5 & no fog & no fog & 6.5 & fog & 0.84 \\
\hline 0.096 & 135.0 & 4.5 & 3.7 & no fog & fog & 5.6 & fog & 0.84 \\
\hline 0.169 & 129.0 & 16.5 & 15.0 & no fog & no fog & 17.0 & fog & 0.82 \\
\hline 0.172 & 135.0 & 15.0 & 14.5 & no fog & fog & 16.3 & fog & 0.82 \\
\hline 0.172 & 137.0 & 16.0 & 14.2 & no fog & no fog & 16.0 & critical value & 0.81 \\
\hline 0.174 & 139.0 & 16.0 & 14.0 & no fog & no fog & 15.9 & no fog & 0.81 \\
\hline 0.176 & 140.0 & 15.0 & 14.0 & no fog & fog & 16.0 & fog & 0.81 \\
\hline 0.176 & 142.0 & 16.5 & 13.8 & no fog & no fog & 15.7 & no fog & 0.81 \\
\hline
\end{tabular}
Figs. 2 and 3 are, in fact, those of water vapour. The mixtures' molar specific heats are evaluated at the

Table 1. Dropwise wall condensation experiments of water vapour in nitrogen 
Table 2. Filmwise wall condensation experiments of n-butyl alcohol in nitrogen

\begin{tabular}{|c|c|c|c|c|c|c|c|c|}
\hline \multicolumn{6}{|c|}{ Johnstone et al. [1] } & \multicolumn{3}{|c|}{ Equations (16) (19) } \\
\hline$\dot{c}_{b}^{+}$ & $t_{\mathrm{b}}[\mathrm{C}]$ & $t_{i}[\mathrm{C}]$ & $t_{4+}[\mathrm{C}]$ & Prediction & Observation & $t_{\mathrm{it}}[\mathrm{C}]$ & Prediction & $L k^{\prime}$ \\
\hline 0.181 & 219.0 & 33.7 & 33.7 & critical value & fog & 31.0 & no fog & 1.41 \\
\hline 0.178 & 229.0 & 35.0 & 32.7 & no fog & no fog & 29.9 & no fog & 1.42 \\
\hline 0.180 & 265.0 & 31.0 & 30.2 & no fog & no log & 27.3 & no log & 1.41 \\
\hline 0.180 & 138.0 & 56.6 & 44.0 & no fog & no fog & 41.3 & nofog & 1.43 \\
\hline 0.180 & 152.0 & 43.9 & 41.5 & no log & fog & 38.8 & no fog & 1.42 \\
\hline 0.182 & 167.0 & 45.9 & 39.3 & no fog & no fog & 36.8 & nofog & 1.41 \\
\hline 0.181 & 212.0 & 38.7 & 34.3 & no fog & no fog & 31.6 & no log & 1.41 \\
\hline 0.180 & 292.5 & 28.2 & 28.2 & critical value & no fog & 25.6 & no fog & 1.40 \\
\hline 0.136 & 95.6 & 54.8 & 49.0 & no log & no tog & 47.5 & no fog & 1.63 \\
\hline 0.140 & 162.3 & 37.0 & 35.3 & no fog & fog & 33.5 & no log & 1.59 \\
\hline 0.1 .36 & 174.0 & 34.7 & 33,3 & no fog & fog & 31.6 & nolog & 1.60 \\
\hline 0.137 & 206.5 & 34.0 & 30.2 & no fog & no fog & 28.4 & no log & 1.59 \\
\hline 0.139 & 209.0 & 31.7 & 30.3 & no fog & $\log$ & 28.2 & no fog & 1.58 \\
\hline 0.139 & 210.0 & 30.3 & 30.3 & critical value & log & 28.3 & no log & 1.58 \\
\hline 0.139 & 210.4 & 33.1 & 30.2 & no log & nolog & 28.2 & no fog & 1.58 \\
\hline 0.138 & 207.5 & 32.2 & 30.5 & no fog & fog & 28.4 & no log & 1.58 \\
\hline 0.139 & 207.5 & 32.8 & 30.6 & no fog & no fog & 28.5 & no log & 1.58 \\
\hline 0.147 & 229.0 & 32.6 & 29.5 & no fog & no fog & 27.4 & no fog & 1.54 \\
\hline 0.149 & 250.0 & 29.1 & 28.0 & no fog & no fog & 26.0 & no fong & 1.53 \\
\hline 0.153 & 250.0 & 28.8 & 28.3 & no fog & no fog & 26.3 & nofog & 1.51 \\
\hline 0.147 & 220.8 & 31.4 & 30.2 & no fog & fog & 28.1 & no $\log$ & 1.54 \\
\hline 0.107 & 122.0 & 38.7 & 37.0 & no fog & no fog & 35.7 & no log & 1.77 \\
\hline 0.107 & 122.0 & 38.5 & 37.0 & no fog & fog & 35.7 & no $\log$ & 1.77 \\
\hline 0.110 & 128.0 & 42.1 & 36.3 & no fog & no log & 35.1 & no & 1.75 \\
\hline 0.106 & 129.0 & 38.7 & 35.3 & no fog & fog & 34.3 & no fog & 1.77 \\
\hline 0.108 & 169.0 & 31.2 & 30.2 & no fog & fog & 28.9 & no log & 1.75 \\
\hline 0.109 & 180.5 & 34.4 & 29.0 & no fog & no fog & 27.8 & no fog & 1.74 \\
\hline 0.110 & 190.0 & 32.9 & 28.0 & no fog & no fog & 26.9 & no log & 1.73 \\
\hline 0.108 & 195.0 & 33.7 & 27.5 & no fog & no fog & 26.2 & no log & 1.74 \\
\hline
\end{tabular}

bulk composition (see equation (9) will $c^{+}$replaced by $c_{\mathrm{b}}^{+}$). The mixtures' thermal conductivities are evaluated at the bulk composition, taking account of their composition following Perry and Green [15]

$$
k=\frac{c_{\mathrm{b}}^{+} k_{\mathrm{v}}}{c_{\mathrm{b}}^{+}+\left(\begin{array}{c}
M_{\mathrm{n}} \\
M_{\mathrm{v}}
\end{array}\right)^{1 / 2}\left(1-c_{\mathrm{b}}^{+}\right) 1-c_{\mathrm{b}}^{+}+\left(\frac{M_{\mathrm{v}}}{M_{\mathrm{b}}}\right)^{1 / 2} c_{\mathrm{b}}^{+}}
$$

All the properties of the two components are evaluated at the bulk temperature. In Tables 1 and 2 the newly determined $t_{\mathrm{a}}$ and calculated $L v^{2}$ are listed.

Table 1 reveals, owing to the effect of equation (21), that all the new $t_{i}$ are larger than those of Johnstone et al. [1]. Accordingly, for most cases $t_{\mathrm{i}}<t_{\mathrm{a}}$ and hence fog formation is predicted, which is in agreement with the experimental observation. However, in a few situations fog is predicted but not observed. This can be explained from the difference between $t_{\mathrm{a}}$ and $t_{\mathrm{i}}$, which is a measure of the degree of supersaturation. In general it follows that fog is not observed when $t_{\mathrm{i}}$ is slightly below $t_{a}$, while visible fog formation occurs when $t_{\mathrm{i}}$ exceeds the critical temperature $t_{a}$ significantly. Table 1 also discloses that, according to the improved tangency condition, no inexplicable situations appear where a critical condition $\left(t_{\mathrm{a}}=t_{\mathrm{i}}\right)$ or even superheating is predicted theoretically, but fog is observed experimentally.
The new results in Table 2 indicatc, however, that the re-determined $t_{i}$ are even lower than those of Johnstone et al. [1]. This is explained by the lact that $c_{p, y}^{+} c_{p}^{+}$is much larger than unity, typically $c_{p, y}^{+} / c_{p}^{+}=3.2$, for all the mixtures considered. This implies an enhancement of $\theta_{1}^{*}$ and reduction of the calculated $t_{21}$, see equations (16) and (17). The observed fog can therefore not be explained with the aid of equations (16)-(19) derived here.

An intersection of $G^{+}(t)$ and $F^{+}(t)$ in the film, as depicted in Fig. 3, may result in log formation as well. This intersection is possible since $\left(L e c_{z^{7}}^{+}\right) / c_{p^{+}, W}$ $<1$ for both mixtures considered (water vapournitrogen, $\left(L e^{\prime} c_{p}^{+}\right) / c_{p . v}^{+} \cong 0.7 ;$ n-butyl alcohol-nitrogen. $\left.\left(L e c_{p}^{+}\right) / c_{p, v}^{+} \cong 0.5\right)$, which implies that $G^{+}(t)$ is a convex curve. A numerical investigation of $G^{+}(t)$ and $F^{+}(t)$ with $t$ ranging from $t_{1}$ to $t_{\mathrm{b}}$ provided evidence for all the mixtures that an intersection of both curves does not occur when superheating was prodicted by the slope condition. That is to say, $F^{\prime \prime}(t)>G^{1}(t)$ in the entire film, thus predicted correctly by slope condition (15) or tangency condition (16). Summarizing, the experimental results obtained with nbutyl alcohol-nitrogen mixtures cannot be explained satisfactorily

The major difference with the water vapour- nitrogen experiments, besides the higher temperatures and different Lewis numbers, is the filmwise condensation of n-butyl alcohol, since no promoter could be found for dropwise condensation. Oleic acid was used by 
Johnstone et al. [1] to promote the dropwise condensation of water vapour. This dropwise condensation implies that the experimental interface temperature is better defined, which might be the reason overall agreement is found only between theory and water vapour-nitrogen experiments.

\section{CONCLUSIONS}

In this paper an improved tangency condition for predicting supersaturation in condensers has been derived. This condition is based on the slopes of the saturation line and film model expressions for the vapour mole fraction and temperature.

It has been demonstrated that supersaturation can be correctly predicted by this condition, irrespective of the value of $\left(\right.$ Le $\left.c_{p}^{+}\right) / c_{p, v}^{+}$, but that for $\left(L e c_{p}^{+}\right) / c_{p, v}^{+}<1$ superheating in mixtures cannot be guaranteed. However, a thorough examination of temperature and vapour mole fraction profiles in various binary mixtures of nitrogen with vapours of water and n-butyl alcohol revealed that the condition correctly predicted superheating.

A comparison of the condition with fog formation experiments of Johnstone et al. [1], concerning dropwise wall condensation of water vapour in air, yields good agreement. If dropwise condensation of n-butyl alcohol had also been achieved by these investigators, complete agreement with theory might have been obtained here.

Acknowledgements-The author would like to thank the management of Akzo Research Laboratories Arnhem for their permission to publish this paper, and Messrs H. P. Korstanje and $G$. Vegt for their support of this work. He also would like to express his gratitude to Prof. A. K. Chesters of Eindhoven University of Technology for his stimulating discussion on the subject.

\section{REFERENCES}

1. H. F. Johnstone, M. D. Kelley and D. L. McKinley, Fog formation in cooler-condensers, Ind. Engng Chem. 42, 2298-2302 (1950).

2. D. P. Sekulic, Irreversible condensation conditions near the cryosurface, Int. J. Heat Mass Transfer 28, 1205 $1214(1985)$.

3. P. Koch, Wärme- und Stofftransport bei laminarer freier Konvektion in feuchter Luf an einer gekühlten vertikalen Platte, Ph.D. Thesis, Technische Universität München (1986) (in German).

4. R. B. Bird, W. E. Stewart and E. N. Lightfoot, Transport Phenomena. Wiley, New York (1960).

5. J. Stefan, Versuche über die Verdampfung, Sher. Akad. Wiss. Wien 68(2), 385423 (1873) (in German).

6. G. Ackermann, Wärmeübertragung und molekulare Stofübertragung in gleichen Feld bei groszen Temperatur- und Partialdruckdifferenzen, VDI ForschHft. 382 (1937) (in German)

7. A. P. Colburn and T. B. Drew, The condensation of mixed vapours, Trans. A.I.Ch.E. 33, 197-212 (1937).

8. H. L. Toor, Fog formation in boundary layer problems, A.I.Ch.E. Jl17, 5-14 (1971).

9. H. L. Toor, Fog vaporization and condensation in boundary layer problems, Ind. Engng Fundam. 10, 121 131 (1971).

10. Y. Hayashi, A. Takimoto and Y. Yamamoto, Heat and mass transfer with mist formation in a laminar duct flow, Heat Transfer -Jap. Res. 10, 37-51 (1981).

11. V.D.I., V.D.I.-Wärmeatlas. 5. Aufl. V.D.I. Verlag GmbH. Düsseldorf (1988) (in German).

12. D. K. Edwards, V. E. Denny and A. F. Mills, Transfer Processes. Hemisphere/McGraw-Hill, New York (1979).

13. R. C. Reid, J. M. Prausnitz and T. K. Sherwood, The Properties of Gases and Liquids, 3rd Edn. McGraw-Hill, New York (1977).

14. Landolt-Börnstein, Bd. II/Sa und Bd. IV/4b, 6. Auf, Springer, Berlin (1960) (in German).

15. R. H. Perry and D. W. Green, Perry's Chemical Engineers' Handbook, 6th Edn. McGraw-Hill, New York (1984).

\title{
UNE CONDITION TANGENTE AMELIOREE POUR LA FORMATION DE BROUILLARD DANS LES CONDENSEURS-REFROIDISSEURS
}

\begin{abstract}
Résumé-En 1950 Johnstone et al. (Ind. Engng Chem. 42, 2298-2302 (1950)) introduisirent la condition tangente pour déterminer la formation de brouillard (ou de buée) dans les mélanges binaires dans les canaux refroidis. Dans la présente analyse on montre que leur condition est erronée et une équation améliorée est obtenue. La condition esł basée sur le transfert diffusionnel de chaleur et de masse à la paroi d'un condenseur et sur la pente de la ligne de saturation du composant vapeur à la température pariétale. On traite l'équation d'énergie et de diffusion dans un flim stagnant près de la paroi le modèle classique du film ou la théorie du film). La validité de la condition tangente améliorée est éprouvée avec les expériences de condensation pariétale faites par Johnstone et al. sur des mélanges d’azote avec des vapeurs d'eau et de n-butyl alcool et on constate un accord satisfaisant.
\end{abstract}

\section{EINE VERBESSERTE BERÜHRUNGSBEDINGUNG ZUR BESTIMMUNG DER NEBELBILDUNG IN KÜHLER-KONDENSATOREN}

\begin{abstract}
Zusammenfassung - Im Jahr 1950 führten Johnstone et al. (Ind. Engng Chem. 42, 2298-2302 (1950)) eine Berührungsbedingung ein, um die Nebelbildung binärer Gemische in gekühlten Kanälen zu bestimmen. In der vorliegenden Untersuchung wird gezeigt, da 3 die damals angegebene Bedingung fehlerhaft ist, weshalb eine verbesserte Gleichung abgeleitet wird. Die Bedingung basiert auf einer Beschreibung der Wärmestromdichte und Massenstromdichte durch Diffusion zur Kondensatorwand, sowie der Steigung der Sättigungskurve der Dampfkomponente bei Wandtemperatur. Die Stromdichten errechnen sich aus den vollständigen Transportgleichungen für Energie und Stoff in einem ruhenden Film in unmittelbarer Nähe der Wand (klassisches Filmmodell, bzw, klassische Filmtheorie). Die Gültigkeit der verbesserten Beruhrungsbedingung wird anhand der Experimente von Johnstone et al, welche die Filmkondensation von Gemischen aus Stickstoff und Wasser-bzw. n-Butylalkohol-Dämpfen untersuchten, geprüft. Es ergibt sich eine zufriedenstellende Übereinstimmung.
\end{abstract}




\title{
ТАНГЕНЦИАЛЬНОЕ УСЛОВИЕ В ОХЛАДИТЕЛЯХ-КОНДЕНСАТОРАХ ПРИ ОБРАЗОВАНИИ ТУМАНА
}

\begin{abstract}
Aннотаиия-В 1950 г. Джонстоун и др. (Ind. Engng Chem. 42, 2298-2302 (1950)) ввели понятие тангенциального условия при образовании тумана (дымки) в бинарных смесях в охлаждаемых каналах. В настояшем исследовании показано, что предложенное условие является ошибочным, и выведено более адекватное выражение. Это условие содержит скорости теплопереноса и диффузионного массопереноса к стенке конденсатора, а также угол наклона линии насыщения пара при температуре стенки. Скорости переноса определены при помощи детального анализа уравнений сохранения энергии и диффузии в прилегающей к стенке неподвнжной пленке (классические “модель пленки" и “теория плекки”). Эффективность использования рассматриваемого условия проверена путем сравнения с экспериментальными данными по конденсации на стенке, полученными Джонстоуном и др. для смесей азота с парами воды и н-бутилового спирта, при этом получено их удовлетворительное согласие.
\end{abstract}

